\title{
Dynamics and kinetics of natural killer cell cytotoxicity in human malaria as evaluated by a novel stepwise cytotoxicity assay
}

\author{
Avaliação da dinâmica e da cinética da atividade citotóxica \\ de células natural killer na malária humana
}

\author{
Fátima Ribeiro-Dias ${ }^{1,2}$ and Carlos Eduardo Tosta ${ }^{1}$
}

\begin{abstract}
Malaria causes important functional alterations of the immune system, but several of them are poorly defined. To evaluate thoroughly the natural killer cell cytotoxicity in patients with malaria, we developed a technique capable to assess both the dynamics and the kinetics of the process. For the kinetics assay, human peripheral blood mononuclear cells were previously incubated with $\mathrm{K} 562$ cells and kept in agarose medium, while for the dynamics assay both cells were maintained in suspension. NK activity from patients with vivax malaria presented a kinetics profile faster than those with falciparum malaria. NK cytotoxicity positively correlated with parasitemia in falciparum malaria. The dynamics of NK cytotoxicity of healthy individuals was elevated at the beginning of the process and then significantly decreased. In contrast, malaria patients presented successive peaks of NK activity. Our results confirmed the occurrence of alteration in NK cell function during malaria, and added new data about the NK cytotoxicity process.
\end{abstract}

Key-words: Malaria. Plasmodium vivax. Plasmodium falciparum. Natural killer cells. Cytotoxicity.

\section{RESUMO}

A malária causa importantes alterações do sistema imunitário, muitas ainda mal definidas. Para permitir uma avaliação abrangente da atividade citotóxica das células natural killer em pacientes com malária, desenvolvemos um teste capaz de avaliar concomitantemente a dinâmica e a cinética do processo. Para a avaliação da cinética, células mononucleares do sangue periférico interagiram com células $\mathrm{K} 562$ e foram mantidas em agarose, enquanto para avaliar a dinâmica as células eram mantidas em suspensão. A cinética da atividade citotóxica das células NK foi mais rápida em pacientes com Plasmodium vivax, do que naqueles infectados com $P$. falciparum. Nestes, houve correlação positiva entre a atividade citotóxica das células NK e a parasitemia. O padrão da dinâmica da atividade citotóxica nos pacientes com malária foi bem diferente daquele apresentado pelos indivíduos sadios. Enquanto nestes, a atividade estava muito aumentada no início da incubação das células, sofrendo posteriormente uma redução, nos indivíduos infectados foram detectados sucessivos picos de atividade citotóxica. Nossos resultados confirmam a ocorrência de alteração funcional das células NK na malária humana e acrescentam novos dados sobre a dinâmica e a cinética da atividade citotóxica.

Palavras-chaves: Malária. Plasmodium vivax. Plasmodium falciparum. Células natural killer. Citotoxicidade.

Plasmodium infection causes an extensive alteration of the immune response of the host, characterized by polyclonal activation of B lymphocytes, production of autoantibodies, increased levels of several cytokines, and activation of lymphocytes and macrophages, which lead to immunodeficiency and autoimmunity ${ }^{191623}$. A less known component of the immune system that also present functional alterations during malaria infection are natural killer cells ${ }^{21} 25$. These cells comprise about $10-15 \%$ of all circulating lymphocytes in humans and are important components of the innate immune system, due to their ability to lyse target cells, and provide an early source of immunoregulatory cytokines ${ }^{8}$. They are characterized by the expression of membrane CD16 and CD56 molecules. Although they share a common progenitor with T lymphocytes,

\footnotetext{
1. Laboratório de Imunologia Celular, Área de Patologia, Faculdade de Medicina, Universidade de Brasília, Brasília, DF. 2. Laboratório de Imunidade Natural, Setor de Imunologia, Instituto de Patologia Tropical e Saúde Pública, Universidade Federal de Goiás, Goiânia, GO.

Address to: Dr. Carlos Eduardo Tosta. Laboratório de Imunologia Celular. Área de Patologia/Faculdade de Medicina/Universidade de Brasília, 70910-000 Brasília, DF, Brasil Tel: 5561 3307-2273; Fax: $55613273-3907$

e-mail: cetosta@unb.br

Recebido para publicação em 27/12/2004

Aceito em 27/7/2006
} 
they lack of the expression of both $\mathrm{CD} 3$ and $\mathrm{CD} 4$ markers ${ }^{18}$, but half of them express CD8 molecules, in the $\alpha / \alpha$ form ${ }^{26}$. Under the influence of cytokines produced during innate immunity, NK cells rapidly become activated and migrate to the site of infection. Upon contact with infected cells they proliferate, release cytokines and influence the development of adaptive immune response and/or destroy the infectious agent ${ }^{5}$. The recent characterization of NK cell receptors revealed a complex system of triggering and inhibitory molecules, although the exact nature of their ligands remains poorly characterized $^{1928}$. Interestingly, NK cells recognize major histocompatibility complex (MHC) class I molecules via membrane receptors that deliver signals that inhibit rather than activate NK-cell cytotoxicity. When target cells lack or express insufficient density of MHC class I molecules, as occurs during infection or tumor transformation, cytotoxicity ensues. NK cellmediated cytotoxicity occurs mainly by the binding of NK cells to target cells and release of preformed granules containing perforin and granzymes in the intercellular space, leading to the lysis of target cells within minutes ${ }^{24}$.

As NK-cell cytotoxicity involves the steps of binding, lysis and recycling in a dynamic process, and since there is no technique available for the simultaneous assessment of these activities, the present investigation aimed at evaluating the dynamics of the NK activity in patients infected with Plasmodium falciparum or $P$. vivax. We also evaluated the NK activity in patients by using a classical single-cell assay described by Bonavida et al ${ }^{4}$ to obtain data about the kinetics of NK activity. Neither the kinetics nor the dynamics of NK activity have been evaluated in malaria patients.

\section{MATERIAL AND METHODS}

Study groups. The malaria group consisted of 19 patients with acute infection, 8 by Plasmodium falciparum and 11 by Plasmodium vivax, acquired in endemic areas of the Amazon region and examined in Brasilia. Sixteen were males and the age varied from 18 to 59 years old. Those infected by $P$. falciparum had an average age of $38.2 \pm 12.2$ and those with $P$. vivax $30.1 \pm 6.6$ years old. Eight patients were primoinfected, 10 reinfected and this information was missing from one. Malaria was diagnosed and the species of the parasite determined by blood smear less than 10 days after the beginning of the symptoms. Blood for testing NK-cell cytotoxicity was collected before starting malaria therapy.

The control group also consisted of 19 healthy individuals who had never been to malaria endemic areas. Sixteen were males and the age ranged from 18 to 49 years old (mean of $33.3 \pm 9.9$ ). They were not taking any drug when NK-cell cytotoxicity was assessed.

This research followed the rules of the Conselho Nacional de Saúde, Brazilian Ministry of Health. All individuals gave their signed consent to participate in this study after being informed about their risks and rights.
Isolation of mononuclear cells. Samples of $10 \mathrm{~mL}$ of venous blood were collected into heparinized vacutainer tubes from patient and control at the same occasion, diluted 1:1 with 0.01M EDTA solution in phosphate buffered saline (EDTA-PBS) pH 7.3, overlaid on Percoll (Pharmacia, Upsalla, Sweden), density 1.077 , and submitted to centrifugation at $1,430 \mathrm{xg}$, for $15 \mathrm{~min}$ at $4^{\circ} \mathrm{C}$. Mononuclear cells (MNC) were collected from the interface blood-Percoll, washed twice by centrifugation with EDTA-PBS, at $640 \mathrm{xg}$ and $160 \mathrm{xg}$, respectively, for $10 \mathrm{~min}$ at $4^{\circ} \mathrm{C}$. Cells were then suspended with complete RPMI 1640 medium buffered with $25 \mathrm{mM}$ Hepes and supplemented with $12 \mathrm{mM}$ sodium bicarbonate, $2 \mathrm{mM} \mathrm{L}$-glutamine, $100 \mathrm{U} / \mathrm{mL}$ penicillin, $100 \mathrm{mg} / \mathrm{mL}$ streptomycin and $5 \%$ fetal bovine serum (FBS - Cultilab, Campinas, Brasil), quantified in a hemocytometer, and viability assessed with $0.1 \%$ trypan blue in PBS pH 7.3. Collected MNC were $94.4 \pm 2.4 \%$ lymphocytes and $5.6 \pm 2.4 \%$ monocytes, and their viability was always higher than $92 \%$ (mean $95.6 \pm 3.4 \%$ ). These cells were considered as effector cells in cytotoxicity assays.

Preparation of target cells. The K562 erythroleukemic cell line was used as target cells in the cytotoxicity assay. These cells were maintained as a continuous cell line in complete RPMI 1640 medium, at an average concentration of $5 \times 10^{5}$ cells $/ \mathrm{mL}$. The medium was replaced three times a week. For the cytotoxicity assay, the cells were centrifuged, resuspended in fresh complete RPMI 1640 medium, and the concentration and viability were determined as described. The viability was always higher than $90 \%$.

Evaluation of the kinetics of NK-cell cytotoxicity by a single cell assay. The single cell assay used here was based on that described by Bonavida et $a l^{4}$. Briefly, samples of $50 \mu \mathrm{L}$ of MNC suspension, at a concentration of $4 \times 10^{6} \mathrm{cells} /$ $\mathrm{mL}$ were added to $50 \mu \mathrm{L}$ aliquots of $\mathrm{K} 562$ suspension, at $4 \times 10^{6}$ cells/mL, into flat-bottomed tissue culture microplates, and individual wells were firmly closed using $0.5 \mathrm{~mL}$ Eppendorf tube caps. The cell mixture was centrifuged at $50 \mathrm{xg}$ for $3 \mathrm{~min}$ at room temperature, followed by $15 \mathrm{~min}$ incubation at $37^{\circ} \mathrm{C}$ under continuous shaking with sliding lateral movements of 20 cycles per minute. For evaluating the spontaneous lysis of target cells, $100 \mu \mathrm{L}$ of $\mathrm{K} 562$ cell suspension were centrifuged at the same conditions of the mixture, but in the absence of effector cells. Suspensions of 100 $\mu$ L of conjugates (MNC:K562 cells) or target cells alone were quickly mixed with $50 \mu \mathrm{L}$ of $1.3 \%$ agarose solution in $\mathrm{PBS} \mathrm{pH} 7.3$, at $39^{\circ} \mathrm{C}$, and $7 \mu \mathrm{L}$ drops were dispensed on microscope slides, previously covered with a thin film of agarose, at the same concentration. After 30sec, slides were immersed into complete RPMI 1640 medium and incubated at $37^{\circ} \mathrm{C}$ in a wet chamber, at an atmosphere of $5 \%$ $\mathrm{CO}_{2}$ in air, for intervals of 60 to $240 \mathrm{~min}$. Following, the slides were incubated with $0.1 \%$ trypan blue in PBS $\mathrm{pH} 7.3$ for $5 \mathrm{~min}$ and rinsed with three changes of $0.3 \%$ formaldehyde in PBS. The preparations were immediately examined by optical microscopy, or were kept in formaldehyde solution $(0.3 \%$ in PBS) for a maximal period of 7 days at $4^{\circ} \mathrm{C}$. Cytotoxicity was 
evaluated by microscopy with 400x magnification, and the following parameters were assessed:

$\mathrm{x}$ : frequency of MNC bound to target cells (total of 200 cells) = conjugates

$\mathrm{y}$ : frequency of MNC associated to lysed target cells (total of 50 conjugates) = lytic conjugates

$z$ : frequency of spontaneous lysis of target cells (total of 200 cells)

The frequency of active NK cells (\% NK activity) was calculated according to the equation: $\% \mathrm{NK}=\mathrm{x} . \mathrm{y} \cdot(1-\mathrm{z}) \cdot 100$

Evaluation of the dynamics of NK cell cytotoxicity. Conjugates and target cells were prepared as described above. After centrifugation of the cell mixture at $50 \mathrm{xg}$ for $3 \mathrm{~min}$ at room temperature, they were incubated for a total period of $240 \mathrm{~min}$ in suspension, under continuous shaking with sliding lateral movements of 20 cycles per minute. After 15 , $30,45,60,120,180$, or $240 \mathrm{~min}$, cell suspensions were gently resuspended with a $50 \mu \mathrm{L}$ micropipette, mixed with agarose and dropped on slides, stained, fixed, examined by microscopy, and evaluated as described above.

Determination of parasitemia. Parasitemia and characterization of parasite species were determined by microscopy of blood thin smears, fixed with absolute methanol, and stained with $10 \%$ Giemsa solution in PBS $\mathrm{pH} 7.2$, by examining 2,000 erythrocytes per preparation.
Statistical analyses. The statistical significance of the results was evaluated, when applied, by Student's t test, analysis of variance for unbalanced incomplete blocks, based on the method of Cochran and $\mathrm{Cox}^{7}$, and correlation by Pearson' s test. The data were represented as mean \pm standard error of the mean.

\section{RESULTS}

Kinetics of NK-cell cytotoxicity in patients with malaria. Individuals infected with P.vivax or $P$. falciparum presented a tendency to higher NK cell activation, as compared to control individuals (Figure 1). No difference was found between the frequencies of conjugates in malaria patients $(9.8 \pm 0.7 \%)$ and control group $(7.9 \pm 0.8 \%, n=19$, Figure $1 \mathrm{~A})$, even when malaria patients were separately evaluated (vivax malaria: $7.5 \pm 0.6$ vs control: $9.1 \pm 0.7 \%, \mathrm{n}=11$, Figure $1 \mathrm{~B}$; falciparum malaria: $8.5 \pm 1.6$ vs control: $10.6 \pm 1.5 \%, n=8$, Figure 1C). Usually, both in controls and in infected individuals the frequencies of lytic conjugates (Figures 1D, E, F) and of the active NK cells (Figures 1G, H, I) increased only after 240 min of incubation, but vivax malaria patients presented a faster kinetics of NK activity, attaining the peak of lytic activity after $60 \mathrm{~min}$ of incubation $(13.3 \pm 1.5$ (60min) vs $9,8 \pm 2.2 \%$ (15min) of lytic conjugates, Figure 1E and $1.2 \pm 0.2(60 \mathrm{~min})$

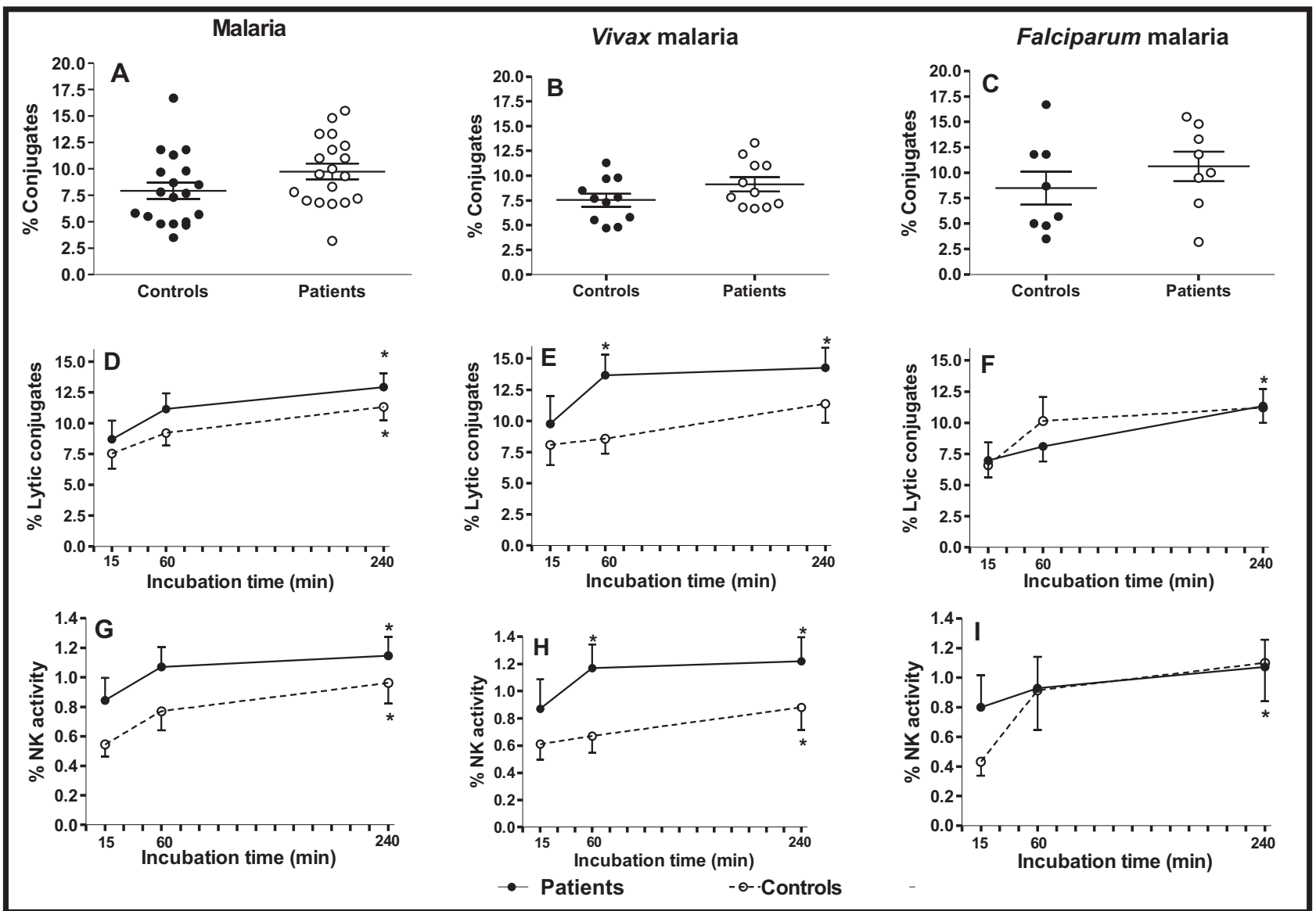

Figure 1 - In vitro active NK cells are early detected in vivax malaria as evaluated by the single cell assay. Control or patient mononuclear cells (effector cells) and $K 562$ cells (target cells) were mixed, centrifuged and incubated for $15 \mathrm{~min}$, and the frequency of conjugates evaluated (A, B, C). Then, cells were resuspended in agarose, dropped on microscope slides and incubated for 60 to $240 \mathrm{~min}$ to evaluate the kinetics of NK activity. After incubation, preparations were stained and the frequency of lytic conjugates $(D, E, F)$ and active $N K$ cells $(G, H, I)$ were determined as described in Materials and Methods.

Data represent mean \pm SEM. Total malaria: $n=19$; vivax malaria: $n=10$ or 11 ; falciparum malaria: $n=7$ or 8 ; *p<0.05: difference between period of incubation (ANOVA for unbalanced incomplete blocks). 
vs $0.9 \pm 0.2 \%(15 \mathrm{~min})$ of NK activity, Figure $1 \mathrm{H}, \mathrm{n}=10$, $\mathrm{p}<0.05)$.

Correlation between NK-cell cytotoxicity and parasitemia.Since NK cells can be activated by direct contact with infected erythrocytes ${ }^{2}$, we evaluated whether parasitemia levels correlated with NK cell activation, as detected by the single cell assay. No correlation was found between parasitemia and the frequency of conjugates (Figures 2A, B, C). However, when patients with low parasitemia $(0.2 \pm 0.08 \%)$ were separately considered, a significant correlation was detected, $(r=0.56$, $\mathrm{p}<0.05, \mathrm{n}=13$, Figure 3D). The frequency of lytic conjugates showed no correlation with parasitemia levels (Figures 3A, B, C). NK activity also presented no correlation with the degree of parasitemia in malaria group or vivax malaria patients (Figures 3D, E). However, the NK activity of falciparum malaria patients $(1.0 \pm 0.2 \%(60 \mathrm{~min}), 1.1 \pm 0.2 \%(240 \mathrm{~min}))$ presented a positive correlation with the levels of parasitemia $(3.2 \pm 1.8 \%$, $\mathrm{r}=0.84, \mathrm{p}<0.05$ (60min), $\mathrm{r}=0.80, \mathrm{p}<0.05$ (240min), Figure 3F).

Dynamics of NK-cell cytotoxicity in patients with malaria. Effect on the binding of effector to target cells: to evaluate the dynamics of NK activity, MNC and K562 cells were incubated in suspension during the whole time of incubation. First we individually analyzed the profile of the binding dynamics and we defined two profiles. The A profile represents a more dynamic binding capacity with peaks of bound cells at different periods of incubation. The $\mathrm{B}$ profile represents a less dynamic binding capacity without significant alterations during the incubation time. In malaria patients (vivax malaria: $57 \%$ A vs $43 \% \mathrm{~B}, \mathrm{n}=7$; falciparum malaria: $50 \%$ A vs $50 \% \mathrm{~B}, \mathrm{n}=6$ ), as well as in control group ( $45 \%$ A vs $55 \%$ $\mathrm{B}, \mathrm{n}=20$ ) there was no predominant profile (data not shown).

\section{Malaria}
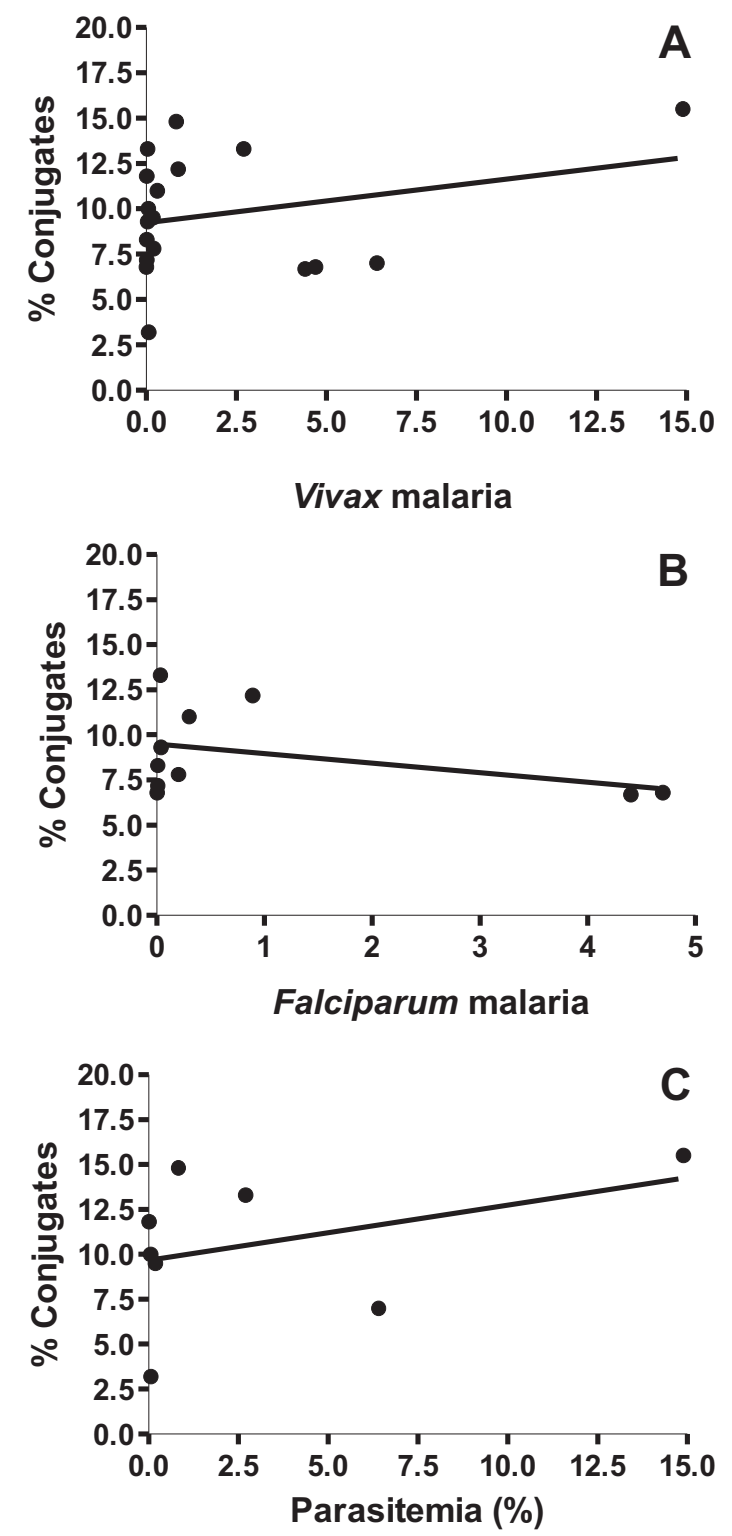

Malaria
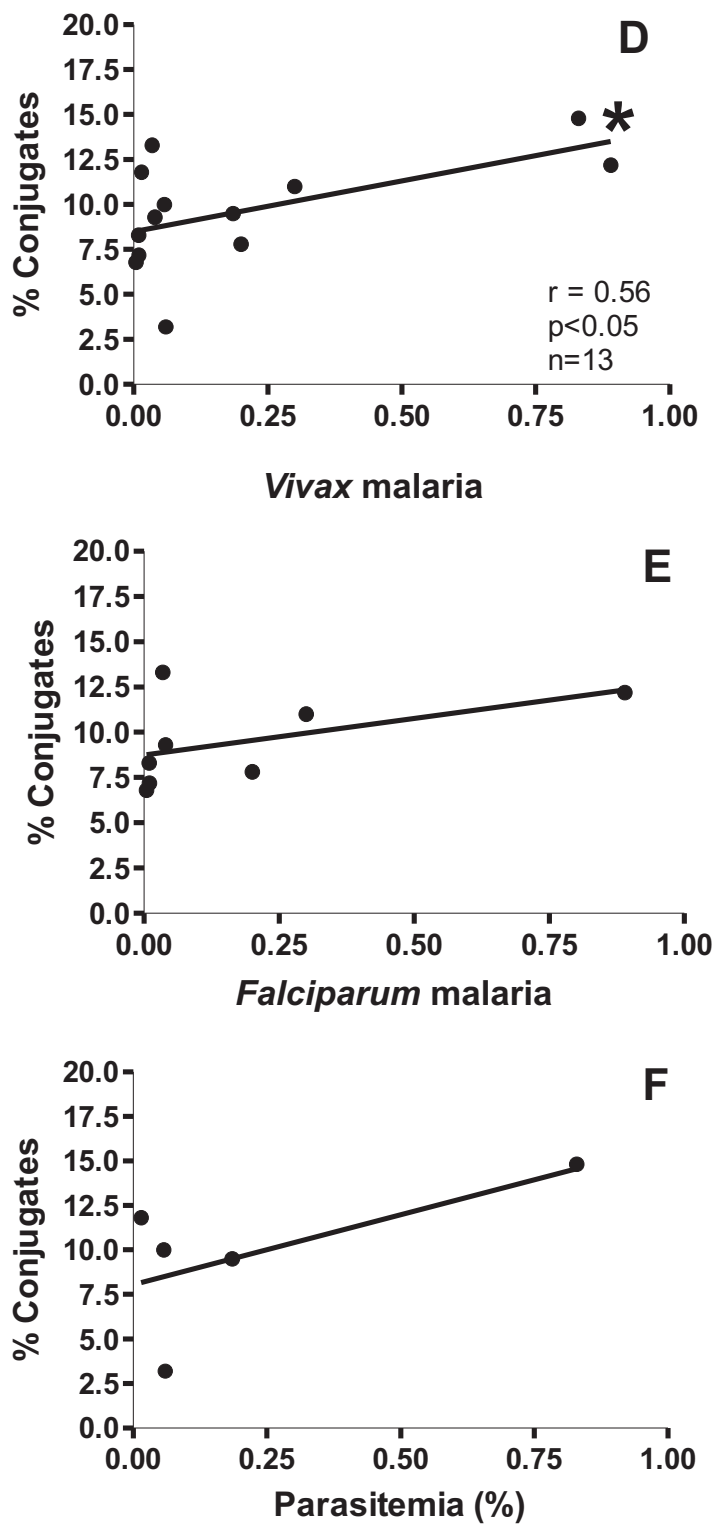

Figure 2 - Correlation between the frequency of conjugates and the levels of parasitemia. MNC were incubated with $\mathrm{K} 562$ cells for 15 min and the frequency of conjugates was determined, as described in Materials and Methods. A, B and $C$ show the data from all patients evaluated $(n=18$, malaria; $n=10$, vivax malaria; $n=8$, falciparum malaria), and $D, E$ and $F$ depict data from patients with low parasitemia. Total malaria: $n=13$; vivax malaria: $n=8$; falciparum malaria: $n=5$; $p<0.05$, Pearson's correlation test. 


\section{Malaria}

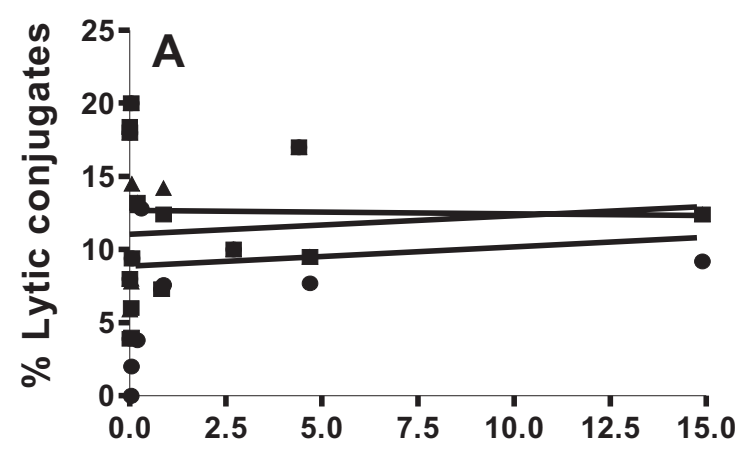

Vivax malaria

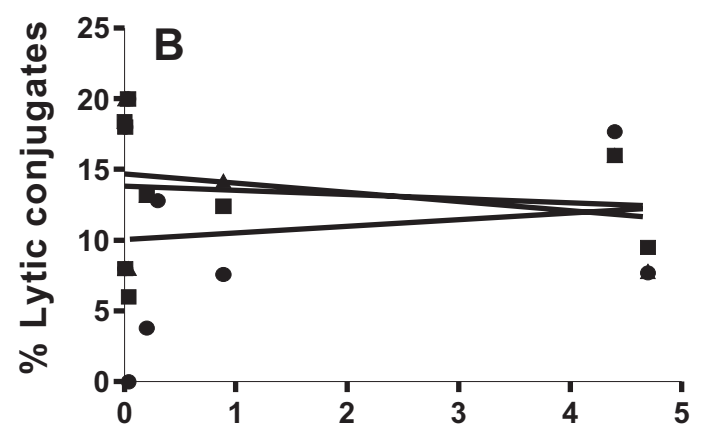

Falciparum malaria

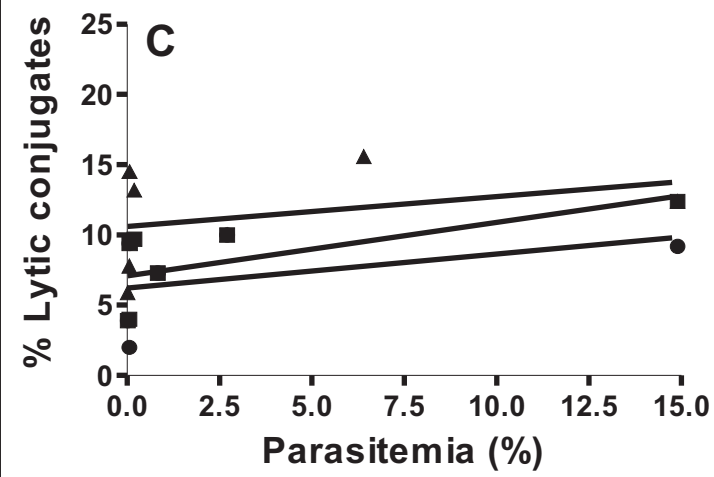

Malaria

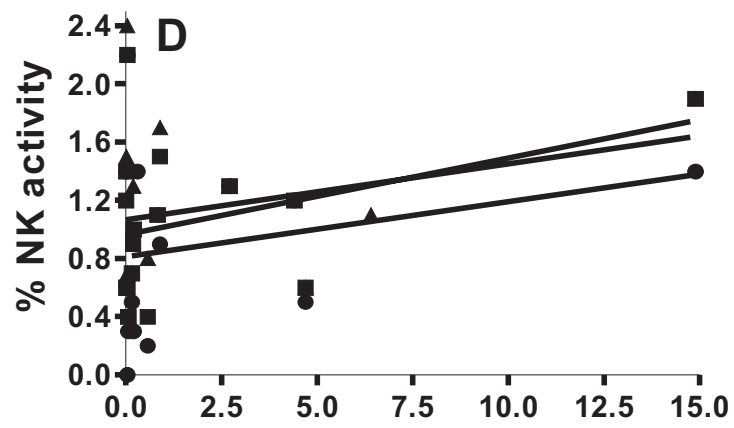

Vivax malaria

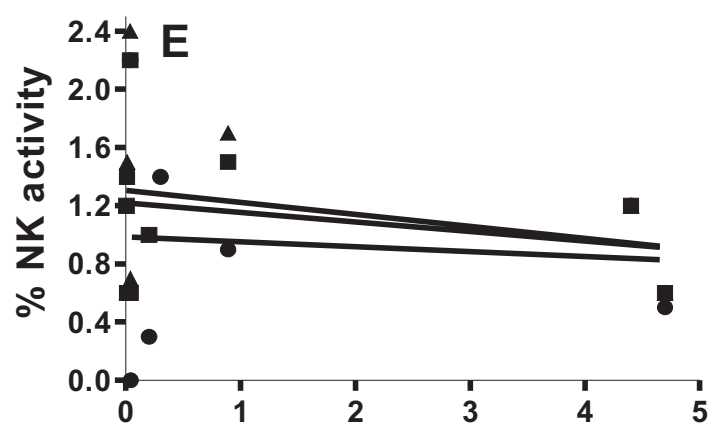

Falciparum malaria

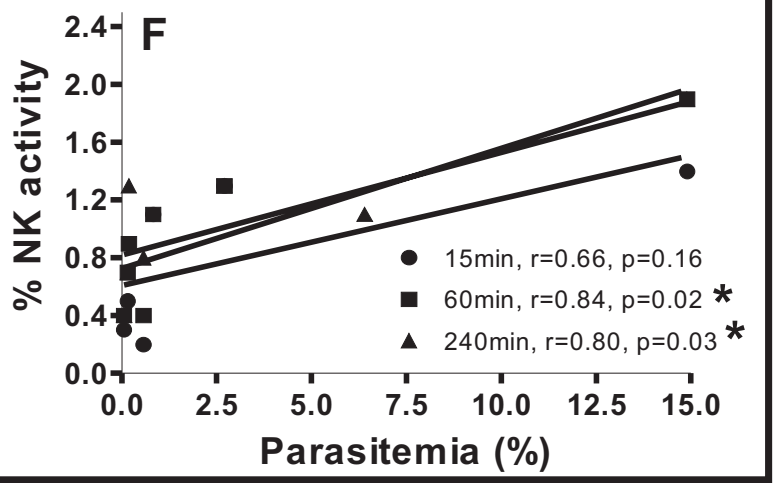

Figure 3 - Correlation between NK activity and the levels of parasitemia. Mononuclear cells (effector cells) were incubated with $\mathrm{K} 562$ target cells for 15 min, then agarose was added and the mixture was dropped on microscope slides. Preparations were incubated for 60 to $240 \mathrm{~min}$ and then stained to determine the frequency of lytic conjugates and $\mathrm{NK}$ activity, as described in Materials and Methods. In $\mathrm{A}, \mathrm{B}$ and $\mathrm{C}$, the frequencies of lytic conjugates are showed, and in $\mathrm{D}, \mathrm{E}$ and $\mathrm{F}$ the frequencies of active $\mathrm{NK}$ cells are presented. *p<0.05, Pearson's correlation test; total malaria: $n=15$ or 18; vivax malaria: $n=9$ or 10; falciparum malaria: $n=8$.

The binding of MNC to target cells was maximal after $15 \mathrm{~min}$ of incubation, decreasing afterwards till $60 \mathrm{~min}$ and then no significant alterations were detected until $240 \mathrm{~min}$, both in malaria patients and controls (Figures $4 \mathrm{~A}, \mathrm{~B}, \mathrm{C}$ ). Effector cells from malaria patients (Figure 4A), Plasmodium vivax-infected (Figure 4B), and $P$. falciparum-infected individuals (Figure 4C) showed a trend toward a higher binding capacity and a slow detachment from target cells was detected in vivax malaria patients as compared to that from controls (malaria: $8.7 \pm 0.8$ vs $5.2 \pm 0.9 \%, \mathrm{n}=12, \mathrm{p}<0.05$; vivax malaria: $8.7 \pm 0.8$ vs $3.9 \pm 0.4 \%, \mathrm{n}=7, \mathrm{p}<0.05 ; 30 \mathrm{~min})$.

Effect on the lytic capacity of effector cells: the lytic capacity of effector cells from malaria patients was comparable to that of controls after $15 \mathrm{~min}$ of incubation (malaria: $8.0 \pm 1.4$ vs $7.9 \pm 1.4 \%, \mathrm{n}=12$; vivax malaria: $8.2 \pm 2.1$ vs $8.1 \pm 2.2 \%, \mathrm{n}=7$; falciparum malaria: $7.6 \pm 1.5$ vs $7.5 \pm 1.9 \%$, $\mathrm{n}=5$; Figures $4 \mathrm{D}, \mathrm{E}, \mathrm{F})$. Following, it was showed a decrease of the lytic capacity, which reached its lowest level after $60 \mathrm{~min}$ of incubation. However, differently from the controls, malaria patients presented later cycles of formation of lytic conjugates (vivax malaria vs controls: $9.1 \pm 1.6$ vs $4.0 \pm 1.6 \%, 180 \mathrm{~min}$, $\mathrm{n}=7, \mathrm{p}<0.05$; vivax malaria $60 \mathrm{~min}$ vs $180 \mathrm{~min}: 4.8 \pm 1.2$ vs $9.1 \pm 1.6 \%, \mathrm{n}=7, \mathrm{p}<0.05$; falciparum malaria $60 \mathrm{~min}$ vs $120 \mathrm{~min}$ : $4.2 \pm 2.8$ vs $9.6 \pm 2.8 \%, \mathrm{n}=5, \mathrm{p}<0.05$ (Figures 4D, E, F).

The individual analysis of the dynamics of lytic capacity shows a predominance of the $B$ profile in all groups evaluated 
Malaria

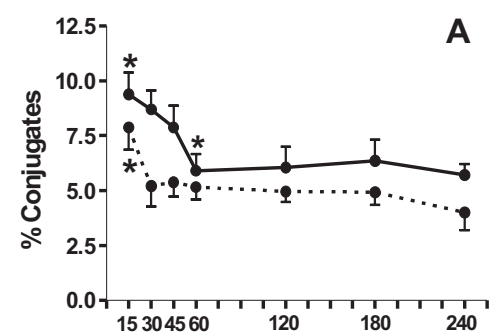

Vivax malaria

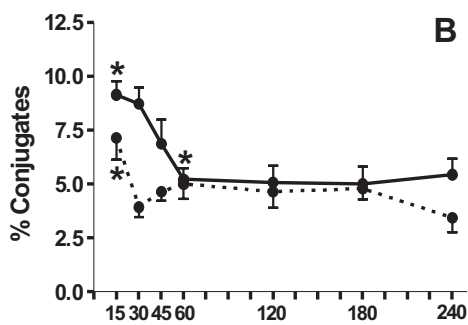

Falciparum malaria

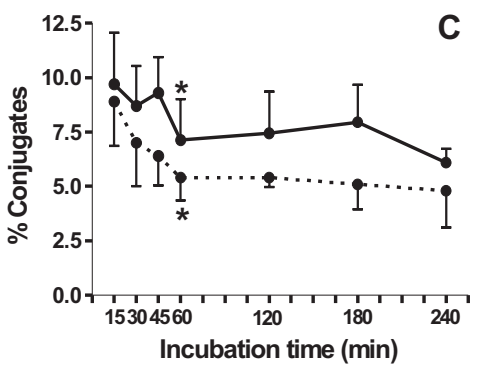

Malaria

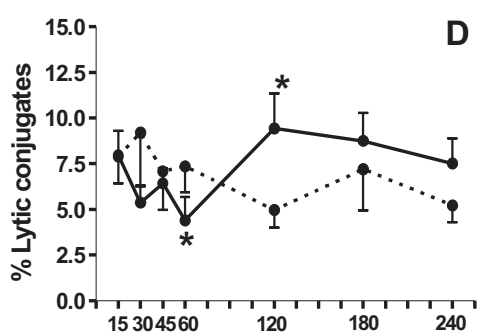

Vivax malaria

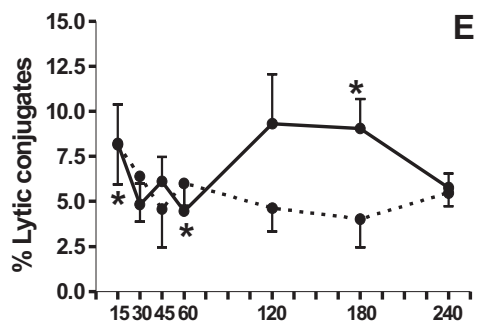

Falciparum malaria

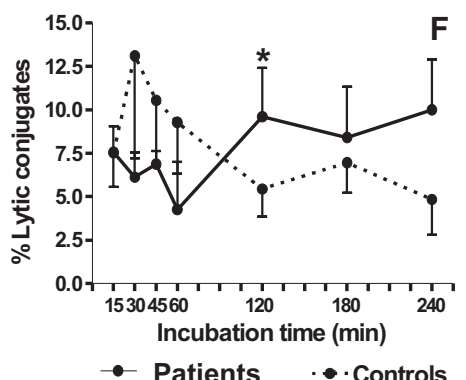

Malaria

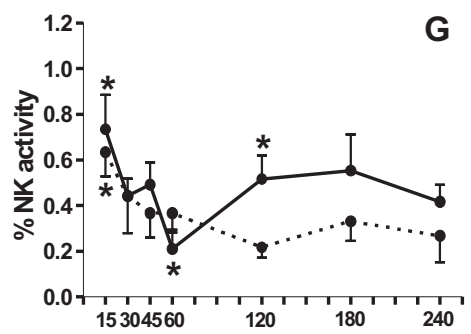

Vivax malaria

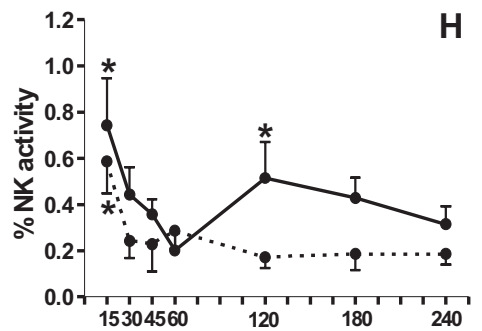

Falciparum malaria

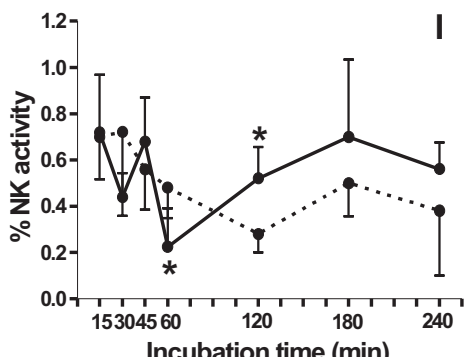

Figure 4 - Dynamics assay reveals early and late cycles of in vitro $\mathrm{NK}$ activity in malaria. Mononuclear (effector) cells were incubated with $\mathrm{K} 562$ (target)cells for different periods of time in suspension. Then, in each time point they were resuspended in agarose, stained and examined. The frequency of conjugates $(A, B, C)$, lytic conjugates $(D, E, F)$, and active NK cells $(G, H$, I) were determined as described in Materials and Methods. Data represent mean \pm SEM, total malaria: $n=12$; vivax malaria: $n=7$; falciparum malaria $n=5$; *p $<0.05$ (differences between incubation time); $\boldsymbol{\theta} \mathbf{p}<.05$ (differences between patients and controls), ANOVA for unbalanced incomplete blocks.

(Controls: $20 \%$ A vs $80 \% \mathrm{~B}, \mathrm{n}=20$; malaria patients: $100 \% \mathrm{~B}$, vivax malaria $\mathrm{n}=7$; falciparum malaria $\mathrm{n}=6$, data not shown).

Dynamics of NK-cell cytotoxicity: the NK cytotoxicity, calculated from data of bound and lytic effector cells in each examined time point showed fluctuations during the $240 \mathrm{~min}$ period of incubation, both in malaria patients and in normal controls. However, malaria patients showed different profiles from those of control individuals, with early and later cycles of NK-cell activity, one at $15 \mathrm{~min}$ and another $120 \mathrm{~min}$ of incubation in both vivax and falciparum malaria (malaria: $0.8 \pm 0.2 \%$ $15 \mathrm{~min} ; 0.2 \pm 0.1 \% 60 \mathrm{~min} ; 0.5 \pm 0.1 \% 120 \mathrm{~min}, \mathrm{n}=12, \mathrm{p}<0.05)$.

\section{DISCUSSION}

NK-cell cytotoxicity involves several steps: the recognition of target by effector cells, the binding and activation of effector cells, the delivery of the lethal hit, and the recycling of the effector cell. Since there is no technique capable of evaluating
NK-cell mediated cytotoxicity in a dynamic way, we developed an assay to evaluate the complete process of cytotoxicity in a stepwise feature. The technical design was based on the singlecell assay ${ }^{4}$, however, both effector and target cells were kept in liquid suspension instead of agarose. The modification allows the evaluation, with a single technique, of the frequency of active NK cells, the speed they lyse target cells and their ability to recycle.

In the single-cell assay, NK activity assessed exclusively the first round of binding cells that are kept immobilized in agarose. Thus, it is possible to evaluate how fast these cells are able to lyse their targets. Here, NK cells from individuals infected with $P$. vivax completed their lytic events very early (60min), in contrast with what occurred with NK cells from $P$. falciparum-infected individuals and controls. In spite of a tendency toward a higher NK cell activation, the frequency of bound cells as well as of lytic cells, or NK activity were not significantly different among malaria patients and controls. As far as we know, this is the first time that the kinetics of NK 
cytotoxic activity is investigated in human malaria. Our data on NK activity and its kinetics in healthy people showed results comparable to those of other authors ${ }^{27} 2932$

Since Plasmodium-infected erythrocytes are in contact with NK cells in blood and organs such as the spleen, we looked for possible correlation between the degree of parasitemia and NK activation, evaluated by the single-cell assay. The frequency of bound effector cells did not correlate with the levels of parasitemia, when the whole group of malaria patients was considered. However, when we considered the subgroup of malaria patients with low parasitemia, a positive correlation was detected. We found that NK activity correlated with parasitemia in $P$. falciparum-infected individuals. This finding is in agreement with that of 0jo-Amaize et $\mathrm{a}^{21}$, but not with Saxena et $\mathrm{al}^{25}$ probably due to technical differences. It appears that low parasitemias induce an increase of molecules involved in recognition or binding of target cells, whereas high $P$. vivax parasitemias could down-modulate these molecules and, consequently, decrease NK activity.

The evaluation of the dynamics of NK cell activity leads to heterogeneous results, particularly in $P$. falciparum-infected individuals. Although it seems to be difficult to define a pattern of dynamics, we observed that some individuals presented high fluctuations in the frequency of binding or lytic cells during the incubation time (we call this high dynamic profile as A profile), while some other presented less fluctuation in those frequencies (we call this low dynamic profile as B profile). Concerning the binding capacity of effector cells, no predominant profile was detected. However, in relation to the frequency of lytic cells, the A profile was predominant in all groups, particularly in malaria patients. The binding dynamics was comparable in patients and controls, but $P$. vivax-infected individuals showed a slower detachment of effector cells from target cells. The detachment of bound effector cells had a peak after $15 \mathrm{~min}$ of incubation, followed by a reduction till $60 \mathrm{~min}$. Only activated NK cells present these early lytic events, as also reported by others ${ }^{142729}$.

We found that the control group did not recover the NKcell activity during the last $180 \mathrm{~min}$ of incubation. This is in agreement with data of Perussia and Trinchieri ${ }^{22}$, who showed inactivation of NK cells after interaction with the target cells, and associated the recycling with the lytic potential of the effector cells. These refractory cells only recovered spontaneously their NK activity after $18 \mathrm{~h}$, or earlier if they were stimulated with cytokines, such as interferon. Thus, our data indicate that in physiological conditions the recycling or in vitro activation of NK cells is low during $240 \mathrm{~min}$ of incubation, although this is not true for all individuals. In contrast, malaria patients presented another cycle of NK activity at 120-180min of incubation. Our data suggest that in vivax malaria this later cycle of NK activity is possibly due to in vitro activation of pre-NK cells, or to recruitment of refractory NK cells at the beginning of the assay, rather than to recycling of effector cells. This interpretation is based on the finding that the frequency of bound cells did not present significant alterations after $60 \mathrm{~min}$ of incubation. In this case, the recycling was probably due to extra cycles of binding, as described by Timonen et $\mathrm{al}^{31}$. These observations, together with the data on the kinetics of NK-cell activity, suggest that in vivax malaria another round of binding and lysis occurs, besides that detected at the first $15 \mathrm{~min}$. In falciparum malaria patients, the later cycle of NK activity is possibly due to a recycling of active NK cells, since a high fluctuation in the frequency of bound cells was frequently observed. To confirm this hypothesis, it will be necessary to enlarge the group of falciparum malaria patients to be evaluated.

The assessment of NK activity in human malaria has generated conflicting results ${ }^{612212530}$, but recent publications presented clear evidence that NK cells are activated in humans with plasmodium infection ${ }^{2}{ }^{13}$. These cells are considered to play a role in immunoregulation, and are required for both innate ${ }^{3}$ and adaptive immunity against malaria parasite ${ }^{11}$, mainly due to their ability to produce IFN- $\gamma$ very early during infection ${ }^{15}$. Besides producing cytokines, NK cells appear to be endowed with the ability to limit parasitemia by means of cytolysis of Plasmodium falciparum-infected erythrocytes ${ }^{17}$.

A great variability has been observed in human NK activity ${ }^{10} 20$ especially among malaria infected individuals. Patients presented at different periods of infection, with various parasitemia, and the blood was collected at different times after schizogony. This variation makes difficult to find statistically significant differences between groups. These limitations are partially circumvented when experimental models are used. However, experimental models are only approximations of reality, and this is particularly true in malaria. In spite of these difficulties we demonstrated here that: a) $P$. vivax-infected individuals presented a fast kinetics of NK activity, completing the lytic events within $60 \mathrm{~min}$; b) in patients with low parasitemia a positive correlation was found between the frequency of bound cells and the degree of parasitemia; c) a positive correlation was detected between NK activity and the levels of parasitemia in $P$. falciparum-infected individuals; d) the process of NK activity is more dynamic in malaria patients than in controls; e) $P$. vivax and $P$. falciparum-infected individuals presented early and later cycles of NK activity, in contrast to healthy individuals, who showed exclusively the early cycle. Our data on the dynamics NK-cell activity were complemented by the results of the kinetics assay. We showed that $15 \mathrm{~min}, 60 \mathrm{~min}$ and $120 \mathrm{~min}$ were time points sufficient to evaluate the dynamics of NK activity.

In conclusion, our investigation corroborated the data on NK-cell activation in patients with both $P$. vivax and $P$. falciparum malaria, and added novel data about the dynamics and kinetics of the NK-cytotoxicity process, which may help to understand the relationships of malaria parasite with the human immune system.

\section{ACKNOWLEDGEMENTS}

The authors are indebted to Renê Pires de Oliveira and José Siqueira da Silva for technical support and to Drs Celso Chiarini and Eduardo Silva for the statistical analysis. The collaboration of Valéria Ginani, Hilton R. Picelli and Paula R. Salviano is gratefully acknowledged. 


\section{REFERENCES}

1. Alves MF, Santos-Neto LL, Junqueira MIM, Tosta CE. Cytokines and dysregulation of the immune response in human malaria. Memórias do Instituto Oswaldo Cruz 87 (supl 3): 331-336, 1992.

2. Artavanis-Askonas K, Eleme K, McQueen KL, Cheng NW, Parham P, Davis DM, Riley EM. Activation of a subset of human NK cells upon contact with Plasmodium falciparum-infected erythrocytes. The Journal of Immunology 171:5396-5405, 2003.

3. Artavanis-Askonas K, Riley EM. Innate immune response to malaria: rapid induction of IFN- $\gamma$ from human NK cells by live Plasmodium falciparuminfected erythrocytes. The Journal of Immunology 169:2956-2963, 2002.

4. Bonavida B, Bradley TP, Grimm EA. The single-cell assay in cell-mediated cytotoxicity. Immunology Today 4:196-200, 1983

5. Carayannopoulos LN, Yokoyama WM. Recognition of infected cells by natural killer cells. Current Opinion in Immunology 16:26-33, 2004

6. Chaicumpa $\mathbb{W}$, Atthasishtha N, Looareesuwan S, Tharavanij S. Natural killer cells in peripheral blood of healthy individuals and patients with malaria. Southeast Asian Journal of Tropical Medicine and Public Health 13:61-68, 1982.

7. Cochran WG, Cox GM. Experimental Design. $2^{\text {nd }}$ edition, John Willey, New York, 1957

8. Cooper MA, Fehniger TA, Caligiuri MA. The biology of human natural killercell subsets. Trends in Immunology 22:633-640, 2001.

9. Daniel-Ribeiro CT, Zanini G. Autoimmunity and malaria: what are they doing together? Acta Tropica 76:205-212, 2000.

10. De La Rocque L, Zalis M, Goulart J, Rumjanek VM. Espectro de atividade NK em um pequeno grupo populacional brasileiro. Revista Brasileira de Cancerologia 34:19-25, 1988 .

11. Doolan DL, Hoffman SL. IL-12 and NK cells are required for antigen-specific adaptive immunity against malaria initiated by CD8+ T cells in Plasmodium yoelii model. The Journal of Immunology 163:884-892, 1999.

12. Gilbreath MJ, Pavanand K, McDermott RP, Phisphumvithi P, Permpanich B, Wimonwattrawatee T. Deficient spontaneous cell-mediated cytotoxicity and lectin-induced cellular cytotoxicity by peripheral blood mononuclear cells from Thai adults naturally infected with malaria. Journal of Clinical Microbiology 17:296-304, 1983.

13. Hermsen CC, Konijnenberg Y, Mulder L, Loe C, van Deuren M, van der Meer JW, van Mierlo GJ, Eling WM, Hack CE, Sauerwein RW. Circulating concentrations of soluble granzyme A and B increase during natural and experimental Plasmodium falciparum infections. Clinical and Experimental Immunology 132:467-472, 2003.

14. Hiserodt JC, Britvan LJ, Targan SR. Characterization of the cytolytic reaction mechanism of the human natural killer (NK) lymphocyte: resolution into binding, programming, and killer cell-independent steps. The Journal of Immunology 129:1782-1787, 1982.

15. Lieberman LA, Hunter CA. Regulatory pathways involved in the infection-induced production of IFN- $\gamma$ by NK cells. Microbes and Infection 4:1531-1538, 2002.
16. Malaguarnera L, Musumeci S. The immune response to Plasmodium falciparum malaria. Lancet Infectious Diseases 2:472-478, 2002.

17. Mavoungou E, Luty AJF, Kremsner PG. Natural killer (NK) cell-mediated cytolysis of Plasmodium falciparum-infected human red blood cells in vitro. European Cytokine Network 14:134-142, 2003.

18. Middleton D, Curran M, Maxwell L. Natural killer cells and their receptors. Transplantation Immunology 10:147-164, 2002.

19. Moretta L, Moretta A. Unravelling natural killer cell function: triggering and inhibitory human NK receptors. The EMBO Journal 23:255-259, 2004.

20. Nagel JE, Collins GD, Adler WH. Spontaneous or natural killer cytotoxicity of $\mathrm{K} 562$ erythroleukemic cells in normal patients. Cancer Research 41:2284-2288, 1981.

21. Ojo-Amaize EA, Salimonu LS, Williams AI, Akinwolere AO, Shabo R, Alm GV, Wigzell H. Positive correlation of parasitemia, interferon titers, and natural killer cell activity in Plasmodium falciparum-infected children. Journal of Immunology 127:2296-2300, 1981.

22. Perussia B, Trinchieri G. Inactivation of natural killer cell cytotoxic activity after interaction with target cells. The Journal of Immunology 126:754$758,1981$.

23. Plebanski M, Hill AVS. The immunology of malaria infection. Current Opinion in Immunology 12:437-441, 2000.

24. Russell JH, Ley TJ. Lymphocyte-mediated cytotoxicity. Annual Review of Immunology 20:323-370, 2002

25. Saxena QB, Biswas S, Sharma VP. Status of natural killer activity in the peripheral blood of P.vivax and P.falciparum malaria patients. Indian Journal of Malariology 25:11-15, 1988.

26. Seaman WE. Natural killer cells and natural killer T cells. Arthritis and Rheumatism 43:1204-1217, 2000.

27. Silva A, Bonavida B, Targan S. Mode of action of interferon-mediated modulation of natural killer cytotoxic activity: recruitment of pre-NK cells and enhanced kinetics of lysis. The Journal of Immunology 125:479-484, 1980

28. Snyder MR, Weyand CM, Goronzy JJ. The double life of NK receptors stimulation or co-stimulation? Trends in Immunology 25:25-32, 2004.

29. Targan SR, Dorey F. Dual mechanism of interferon augmentation of natural killer cell cytotoxicity (NKCC). Annals of the New York Academy of Sciences 350:121-129, 1980

30. Theander TG, Pedersen BK, Bygbjerg IC, Jepsen S, Larsen PB, Kharazmi A Enhancement of human natural cytotoxicity by Plasmodium falciparum antigen activated lymphocytes. Acta Tropica 44:415-422, 1987.

31. Timonen T, Ortaldo JR, Herberman RB. Analysis by a single cell cytotoxicity assay of natural (NK) cell frequencies among human large granular lymphocytes and of the effects of interferon on their activity. The Journal of Immunology 128:2514-2521, 1982.

32. Ulberg M, Jondal M. Recycling and target binding capacity of human natural killer cells. Journal of Experimental Medicine 153:615-628, 1981. 